\title{
The Potential of Indonesia in the Utilization of Mobile Learning in Vocational High School
}

\author{
Sirwan $^{1}$, Nurkhamid ${ }^{2}$ and Ridwan D. Mahande ${ }^{3}$ \\ ${ }^{1}$ Tachnology and Vocational Education, Universitas Negeri Yogyakarta \\ ${ }^{2}$ Electronics Education, Universitas Negeri Yogyakarta \\ ${ }^{3}$ Educational Technology, Universitas Muhammadiyah Makassar
}

sirwan.2016@student.uny.ac.id, nurkhamid@uny.ac.id,and ridwandm@unismuh.ac.id

\begin{abstract}
This study aimed to reveal and know the potential use of mobile learning on the competency test of computer and network engineering vocational schools. The method used in this research was survey method. The Data was collected from August 2017 until December 2017. The research sites were in three vocational schools, SMK Negeri 8 Jeneponto, South Sulawesi, SMK Telkom Makassar, South Sulawesi, and SMK Negeri 1 Depok Sleman, Yogyakarta. The subjects of this study were class XII Computer and Network Engineering with the number of respondents were 120 students. The instrument used to collect data was a questionnaire enclosed. Data obtained used stratified random sampling technique descriptively and statistically analyzed using SPSS. The survey results showed the aspects of mobile device ownership were $100 \%$ of the 120 respondents had mobile device, $0 \%$ who did not have a mobile device. The average type of mobile devices owned by students was IPhone at around 41.7\%, Oppo 32.5\%, Advan 10\% and Samsung 5\%. While from the aspect of the use of mobile devices from 120 respondents showed that the average student accessed social media whatsapp was about $50.8 \%$, Facebook $28.3 \%$, Instagram $8.3 \%$, Line $7.5 \%$ and educational application $4.2 \%$.
\end{abstract}

Keywords: Potential utilization, Mobile learning, the Industrial Revolution 4.0, Vocational High School

\section{Introduction}

The world is facing industrial revolution era 4.0. This era more emphasizes on the digital economy pattern, artificial intelligent, big data, and the rapid development of robotic [1]. Industry 4.0 changes traditional manufacturing relationships to higher skilled labor for monitoring and managing the factory of future [2]. Industrial revolution 4.0 changes the order of the world needs. The old passion of working by using human resource will shift by creating a new order of the jobs that use digital technology which is more flexible, faster and cheaper [3].

The changes are not only affecting the world of employment but also in education domain, especially on classroom learning. The advance in technology confirms on both technological aspect and innovation skills in preparing students' competency to be conducted [4]. Therefore, in order to prepare the industrial revolution era 4.0 the teaching field is required to change in accordance with the era of the industrial revolution 4.0. The phenomenon is often referred to as disruptive innovation [1]. Disruptive is about a technology innovation. Technology encourages variety of changes, not only in technology but also in human life, for instances the way of human communicates and the way of human organizes. Disruption initiates the birth of new innovations including education. Learning should be upgraded to the utilization of digital technology (online). The birth of the internet encourages learning with a different concept, with the use of electronic learning (e-learning). Elearning is the delivery of learning materials through an electronic media such as the internet, intranet/extranet, satellite broadcast, audio/video tape, interactive TV, CD-ROMs, and computer based 
training [5]. E-learning was as an innovative approach to interactive learning materials to send to anyone, anywhere, anytime, used various attributes and resources of various digital technologies in the learning environment as an open, flexible and distributed [6].

The presence of e-learning is a new innovation in electronic learning (e-learning). However although e-learning has many strengths there are still some weaknesses in the use of e-learning. It is the awareness and the ability of users to take advantage of e-learning learning is still low, the availability of infrastructure, need a big cost and time of development that requires considerable time [7]. Furthermore, these problems will be resolved with the widespread use of mobile devices among teachers and students in education [7]. Mobile learning is a type of e-learning as a method for distance education using computer technology and the Internet, which offers learning through mobile devices, such as cell phones, smartphones, PDAs and Tablet [8].

The global digital survey shows that almost half the world's population uses the internet with a total of 3.75 billion users, while almost two-thirds of the world's population are active on the internet using a mobile phone with a percentage of 55\%. From 3.75 Internet users in the world, Indonesia was ranked fourth in the world with the highest percentage at 34\% under India 40\%, United Arab Emirates 46\% and Saudi Arabia 73\% [9]. The development and ownership of smartphones mobile devices relevant to the research that is conducted by the association of Indonesian internet service operation (APJII) in 2000 internet users in 42 cities in Indonesia showed that $85 \%$ of Internet users in Indonesia is more often connected via smartphones [10]. therefore it APJII identified that Internet users via Phone/smartphones 85\%, 32\% laptops, computers 14\% and tablets 13\% [10]. From these data illustrate that Indonesia has great potential in the use of learning-based on mobile learning in vocational high schools (SMK).

Research on mobile learning has been widely carried out, such as mobile technologies in engineering education [11], the mobile learning for education: benefits and Challenges [12], Defining mobile learning in the higher education landscape [13]. Some of these studies only examine the problems of implementing mobile learning in higher education and technical education, no studies have investigated the potential use of mobile learning in vocational secondary school level. This study focused on the potential use of mobile device (mobile learning) in vocational high schools.

In line with a survey of the global digital and research of APJII can be seen that the device Mobile smartphone into a current trend. Almost all the elements are relevant to humans who already have mobile devices including students in vocational high schools. In correlation with mobile devices usage by students, it needs to be particular concern to all elements of educators in schools that use mobile devices for learning. The next use of mobile devices in the learning needs of particular concern them are still many teachers who do not know the learning needs in accordance with the industrial revolution era 4.0, the lack of understanding of teachers in using online learning as well as the unavailability of the online learning infrastructure at schools.

Based on the description of the problem, it is important to do research to determine the potential benefits of mobile learning devices in the industrial era 4.0, in the review of aspects of the use of mobile devices and mobile device ownership aspect. Based on mobile devices, which associated with the activity of students that in the use of mobile devices was at the school and outside the school environment. While the mobile device ownership aspects relating to the status of ownership of mobile devices by students. This study becomes important in order to anticipate the use of mobile devices in a negative that could result in a change in attitude in the students, the students' cognitive changes and changes in the student's skills.

\section{Literature Review}

Vocational high school (SMK) is part of the education system that prepares someone to be able to work on one job group or an occupation of the other creative fields [14]. Vocational education is any that provides experiences, visual stimuli, affective awareness, cognitive information, or psychometric skills, and that enhances the vocational development processes of eksploring, establishing, and maintaining one self in the world of work [15]. Tradition of vocational education aimed at preparing graduates for work. To be ready to work the vocational education training specifically designed to load the appropriate instruction teacher or instructor with a focus on the development needs of the 
industry [16]. Based on the expert opinion of the above, it was concluded that vocational education is education that prepares in the form of individuals skills to prepare for the challenges of the working world and be able to defend themselves to continue to compete in the world of work.

Along with the development of Information and Communication Technology brings the world of work changes in the profile of the first to use human power will shift to the use of digital technology. This is often called a disruptive era, which will be a big change in the economy and the business sector, not only that, education needs to adjust to the conditions of the industrial revolution 4.0 changes traditional manufacturing industries relationships to higher skilled labor for monitoring and managing the factory of the future [2]. Industrial revolution 4.0 changes the order of the world needs the old work and creates a new order of the jobs by using human power will shift to the use of digital technology more flexible, faster and cheaper [3]. Therefore it is very important to do the adaptation of work, workers must also be willing and able to continuously new skill like learning capacity, teamwork, responsibility and problem solving [2]. So, it is to be effective in the need of approaches to technology-based learning, which shows about learning by doing, e-learning, training and traditional training immersive [2].

Mobile learning is certainly not merely the conjunction of 'mobile' and 'learning'; it has always implicitly meant 'mobile e-leaning' and its history and development have to be understood as both a continuation of 'conventional' E-learning and reaction to this 'conventional' e-learning and to its perceived inadequancies and limitation [11]. M-learning is a relatively new trend in the development of e-learning with the help ofdevice a mobile so that users have access to the learning materials anywhere, anytime [17]. M-learning is a type of e-learning, a method for distance education using computer and internet technology, the which offers education learning throught hanheld wireless devices like PDAs, tablet PCs, smart phones and mobile phones [8]. M-learning is a type of elearning, a method for distance learning using computers and the Internet, which offers learning through mobile devices, such as mobile phones, smartphones, and tablet PCs [7]. Simply put, it can be defined that mobile learning is learning that uses a variety of learning contexts, both social and interactions of matter by using personal electronic appliances.

The use of mobile devices in learning provides advantages such as learning can occur anywhere and anytime, access to learning information quickly and widely affects student performance in learning environment, two-way interaction and content collaboration between teachers and students, variations of learning that allows students to get knowledge at their own pace, and motivation with multimedia resources can make learning enjoyable [18]. This has been demonstrated in research conducted at osmania University, India on mobile learning for educatioan: benefits and challeges show that learning mobile learning can be done anywhere, anytime and anywhere [12]. Relevant research conducted in west chester University of Pennsylvania, USA who studied the potential of mobile device utilization tools in higher education where the results showed that from 112 students 42 students prefer using mobile devices to access learning content [19]. From some previous studies still focused on higher education. This study examines the utilization of mobile learning in vocational high schools (SMK) in Indonesia.

\section{Methodology}

This study used statistical descriptive research with quantitative approach by using survey method. The data was taken from from August 2017 to December 2017. The research was conducted in three vocational hight schools. They are SMK Negeri 8 Jeneponto located in Jeneponto district, South Sulawesi, SMK Telkom Makassar, South Sulawesi, SMK Negeri 1 Depok Sleman, Yogyakarta. The research subject was class XII Computer Engineering and Networks with the number of respondents were 120 students selected by stratified random sampling technique. The instrument used to collect data was questionnaire enclosed in which all options answer been provided by the researchers. Data were analyzed by descriptive statistics using SPSS. 
Sirwan, The Potential of Indonesia in the Utilization of Mobile Learning in Vocational High School

\section{Results and Discussion}

\subsection{Result}

Table 1 The Characteristic Respondents

\begin{tabular}{|ll|r|r|r|}
\hline \multirow{2}{*}{} & & \multicolumn{2}{|c|}{ Age } & \\
\cline { 3 - 4 } & & 18 Years & Above 18 Years & Total \\
\hline Gender & Male & 36 & 34 & 70 \\
& Female & 25 & 25 & 50 \\
Total & & 61 & 59 & 120 \\
\hline
\end{tabular}

Based on Table 1 it can be seen, there were 36 respondents male under the age of 18 had already used mobile devices, and age above 18 was only 34 respondents. While female gender under age 18 was only 25 people, and over the age of 18 was 25 people.

Table 2. The Table Frequency of students Gender

\begin{tabular}{|ll|r|r|r|r|}
\hline & & & & Cumulative \\
Prequency & Percent & Valid Percent & \multicolumn{1}{c|}{ Percent } \\
\hline Valid & Male & 70 & 58.3 & 58.3 & 58.3 \\
& Female & 50 & 41.7 & 41.7 & 100.0 \\
& Total & 120 & 100.0 & 100.0 & \\
\hline
\end{tabular}

Table 2 shows that the percentage of male was $58.3 \%$, while the percentage of female was only $41.7 \%$. Based on Table 1 and Table 2. It could be concluded that these data indicated that the level of ownership of mobile devices on vocational education was dominated by men at the age of 18 , compared to women in the age of 18 and above 18 .

Table 3. The Frequency of Students Mobile Devices Based On Types

\begin{tabular}{|ll|r|r|r|r|}
\hline & & Frequency & Percent & Valid Percent & Cumulative Percent \\
\hline SVal & samsung & 6 & 5.0 & 5.0 & 5.0 \\
id & Apple / & 50 & 41.7 & 41.7 & 46.7 \\
& Iphone & & & 79.2 \\
& Oppo & 39 & 32.5 & 32.5 & 89.2 \\
advan & 12 & 10.0 & 10.0 & 91.7 \\
Xiomi & 3 & 2.5 & 2.5 & 97.5 \\
Nokia & 7 & 5.8 & 5.8 & 100.0 \\
huawei & 3 & 2.5 & 2.5 & \\
Total & 120 & 100.0 & 100.0 & \\
\hline
\end{tabular}

Based on Table 3 it can be seen that out of 120 students, Apple /Iphone was the highest score with 50 students, oppo 39 students, Advan 12 students, Nokia 7 students, samsung 6 students and Xiomi and Huawei each 3 students. The data showed that the average student had mobile devices Apple / Iphone. 
Sirwan, The Potential of Indonesia in the Utilization of Mobile Learning in Vocational High School

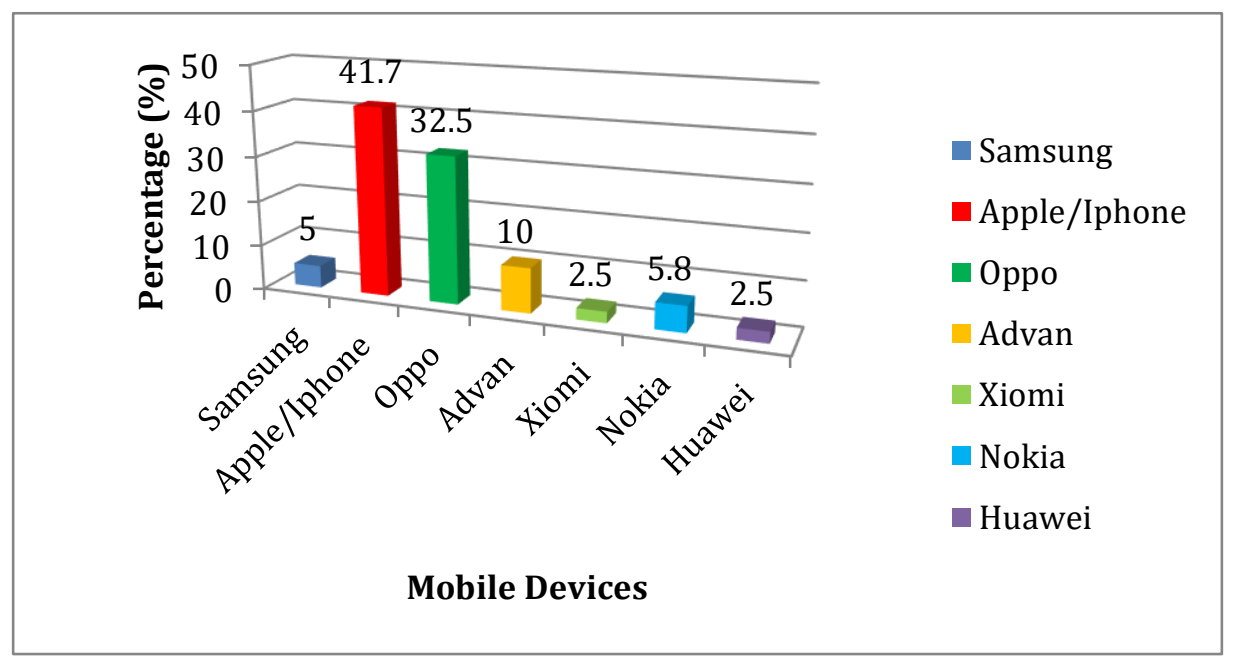

Figure 1. The Percentage of Mobile Devices Owned By Students

Figure 1 indicates that the percentage of mobile devices possessed by student was Apple / Iphone 41.7\%, Oppo 32.5\% , Advan 10\%, Nokia 5.8\%, Samsung 5\%, Xiomi and Huawei $2.5 \%$. The data illustrated that an average of 120 students used a mobile device Apple / Iphone.

Table 4 The Survey of Results Devices that Are often Used by Students

\begin{tabular}{|c|c|c|c|c|c|}
\hline & Frequency & Percent & Valid Percent & Cumulative Percent \\
\hline \multirow[t]{4}{*}{ Valid } & Computer PC & 2 & 1.7 & 1.7 & 1.7 \\
\hline & Laptop & 3 & 2.5 & 2.5 & 4.2 \\
\hline & Smartphone & 115 & 95.8 & 95.8 & 100.0 \\
\hline & Total & 120 & 100.0 & 100.0 & \\
\hline
\end{tabular}

Based on data from Table 4, it can be seen that the devices frequently used by students were Smartphone devices with total numbers of 115 students from 120 students. Laptop was 3 and PC Computers was only 2 people. The data illustrated that the potential of mobile learning usage was at school and would be very supportive because it was supported by the hardware requirements which had been already sufficiently available.

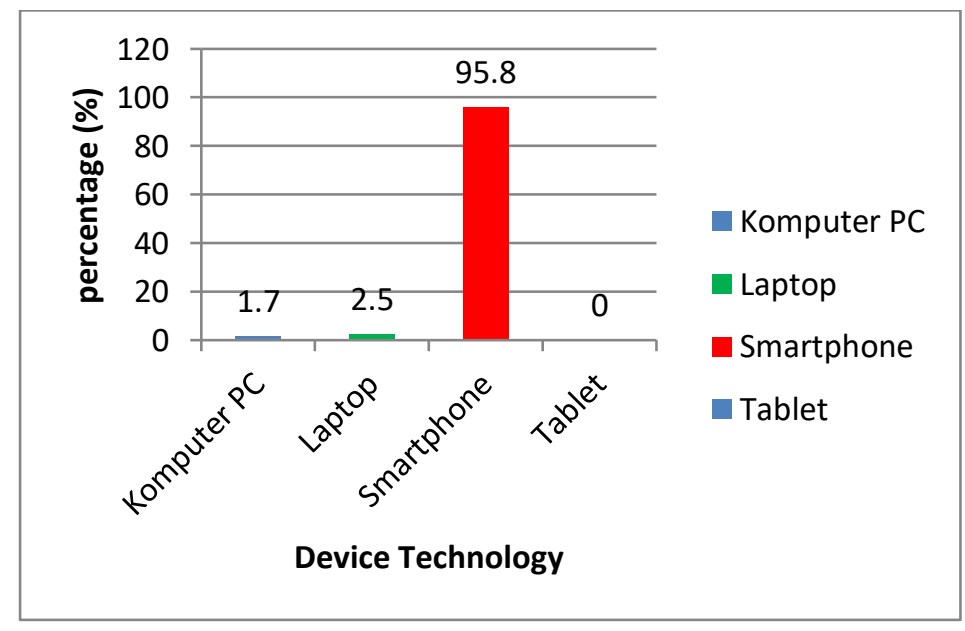

Figure 2. The device which is often used by students 
Sirwan, The Potential of Indonesia in the Utilization of Mobile Learning in Vocational High School

Figure 2 shows 120 secondary vocational students, average students in a day more often used smartphone mobile device with the percentage of $95.8 \%$, laptop computers $2.5 \%$ and $1.7 \%$. From these data illustrated that the potential benefits of mobile-based learning was enormous.

Table 5. The Application of social media which is often used students

\begin{tabular}{|ll|c|c|c|c|}
\hline & & Frequency & Percent & $\begin{array}{c}\text { Valid } \\
\text { Percent }\end{array}$ & $\begin{array}{c}\text { Cumulative } \\
\text { Percent }\end{array}$ \\
\hline Valid & Facebook & 34 & 28.3 & 28.6 & 28.6 \\
& Instagram & 10 & 8.3 & 8.4 & 37.0 \\
& Line & 9 & 7.5 & 7.6 & 44.5 \\
& Whatsapp & 61 & 50.8 & 51.3 & 95.8 \\
& Education App & 5 & 4.2 & 4.2 & 100.0 \\
& Total & 119 & 99.2 & 100.0 & \\
Missing & System & 1 & .8 & & \\
Total & & 120 & 100.0 & & \\
\hline
\end{tabular}

Based on table 5 overall that the applications were often used by students was whatsapp as the most popular with 61 students, Facebook 34 students, instagram 10 students, line 9 students and educational applications were 5 students. The results of the analysis showed that it turned into a day, the students were more often opened whatsapp compared to educational applications. The data illustrated that mobile devices owned by the students had not been used as a medium of learning.

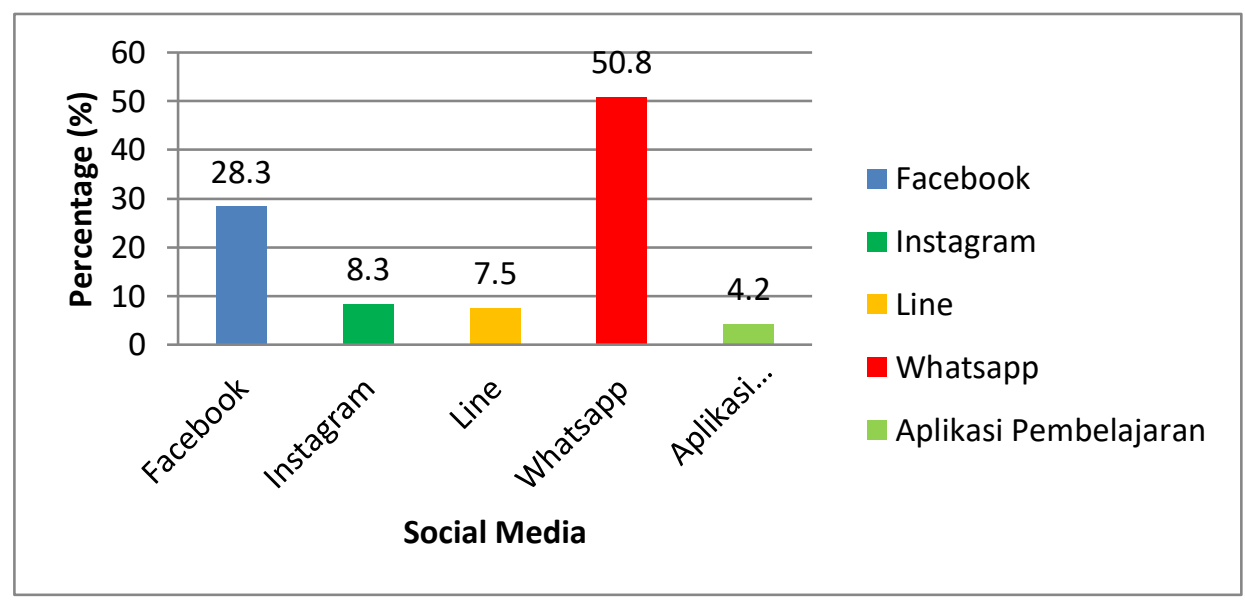

Figure 3. The Percentage of social media applications which are often used by students

Based on Table 5 and Figure 3 it can be concluded that the average student had not utilizing mobile devices as learning media. From 120 students, 50.8\% of students only used them for accessing whatsapp, $28.3 \%$ accessed facebook, instagram accessed 8.5\%, 7.5\% accessed Line, and $4.2 \%$ accessed educational applications. The data showed low utilization of mobile devices in the classroom learning.

\subsection{Discussion}

Based on Table 1 it can be analyzed that characteristic of student was in stable condition with 120 vocational high school students, 70 male students were at age 18 , while female students were only 50 students with the age of 18 to 19 and older. The percentage of the greatest number was $58.3 \%$ for male and $41.7 \%$ for female from 120 students, a total for male students in age 18 was 36 students. While above age 18 was only 34 students. The number of women in age 18 was 25 students and above 18 was only 25 students. This condition made it clearer that mobile technology had entered the world of education. The change occurs so that the habits of students turns into the use of mobile technology 
Sirwan, The Potential of Indonesia in the Utilization of Mobile Learning in Vocational High School

develops fast. Based on data in Table 1 turned out to be more relevant to conduct survey on global digital that showed almost half the world's population used internet with a total of 3.75 billion users, while almost two-thirds of the world's population were active on the internet used mobile phone with a percentage of $55 \%$.

\section{Aspects of mobile device ownership}

If viewed from the aspect of mobile device ownership, based on Table 2 and Figure 2 it can be seen that the average student used mobile devices Apple/IPhone with a percentage of $41.7 \%$, Oppo $32.5 \%$, Advan 10\%, Nokia 5.8\%, Samsung 5\%, Xiomi and Huawei $2.5 \%$. This condition clarified that each student had already had mobile devices. These data were relevant to the research conducted by the association of Internet service providers (APJII) with 2000 internet users in 42 cities in INDONESIA showed that $85 \%$ of Internet users in Indonesia were more often connected via smartphones [10], APJII also identified that internet users via Phone / smartphones were $85 \%, 32 \%$ used laptops, computers were $14 \%$ and tablets were $13 \%$. Based on the results of APJII, it was relevant to the survey results by the researchers that in the sphere of vocational high school (SMK), which consisted of 120 students, found that the average student in a day more frequently used Mobile devices/smartphone with a percentage of $95.8 \%, 2.5 \%$ and Laptops/PC was only $1.7 \%$. This data showed that the level of student habits were more likely to use mobile device/smartphone. This will certainly had a negative impact if education did not anticipate the habits in the use of mobile devices.

\section{Aspects of Utilization of Mobile Devices}

The results showed that, in the table 5, the utilization rates were more likely to use mobile devices to access social media (facebook, instagram, line, whatsapp) while the use of mobile devices for learning Was still very limited. From 120 students on average use of mobile devices in daily used was Whatsapp with a percentage of $50.8 \%$, facebook was $28.3 \%$, Instagram was $8.3 \%$, Line was $7.5 \%$ and for educational applications was only $4.2 \%$. These data indicated that the mobile device if not used properly would have a negative impact on the cognitive development of students, student habits and student learning achievement. From these data it was also seen that the level of mobile usage devices with the lowest percentage was only $4.2 \%$. This showed that mobile device had not used yet in the world of education as a medium of learning.

\section{Conclusion}

Learning needs the help of technology, the appropriate technology is to be applied in the study with the aim of improving the efficiency, effectiveness, and increases the ability of students' critical thinking, independence, creative and innovative. Mobile learning comes into learning by utilizing mobile devices of students. The survey results showed: the aspects of mobile device ownership were $100 \%$ of 120 respondents had mobile device, $0 \%$ who did not have mobile device. Type of mobile devices owned by students was the average of Apple/Iphone with a percentage of $41.7 \%, 32.5 \%$ was Oppo, samsung was $10 \%$, Advan was 5\%. While from the aspect of mobile devices usage from 120 respondents showed that the average student accessed social media like whatsapps with percentage of $50.8 \%$, facebook was $28.3 \%$, instagram was $8.3 \%$, line was $7.5 \%$ and educational application was $4.2 \%$.

Future studies needs to be done on a broader scope because the research is still confined to the sphere of vocational high schools, which consist of 3 vocational schools in Indonesia namely SMK Negeri Jeneponto South Sulawesi, SMK Telkom Makassar South Sulawesi and SMK Negeri 1 Depok Sleman Yogyakarta. Scope of this research is still limited on the aspects of mobile device usage and ownership aspects of mobile devices. The recommendation for further research, research-based mobile learning product is also possible such as educational applications (app education).

\section{Acknowledgement}

I would like to thank to Indonesia Endowment Fund for Education (LPDP) Ministry of Finance Republic Indonesia for always giving supporting author by scholarship. Thank to Director and lecturer in Technology and Vocational Education Department, Yogyakarta State University, especially my supervisor Nurkhamid, Ph.D for

UNY 2018

Copyright (C) 2018 
Sirwan, The Potential of Indonesia in the Utilization of Mobile Learning in Vocational High School

support and guidance. I also thank to Dr. Ridwan Daud Mahande for the guidance on writing paper. Best regards my parents, big family and all friends always pray and support me for phinishing this paper.

\section{References}

[1] FIMI Dataset Repository, http://sumberdaya.ristekdikti.go.id/index.php/2018/01/30/era-revolusiindustri-4-0-saatnya-generasi-millennial-menjadi-dosen-masa-depan/ Retrieved 30 Januari, 2018.

[2] Ngan, Cheng, Hwa. "The Germany-Malaysian Institute Perspektif: Utilizing Technology To Create New pathways for TVET delivery The development of Holistic Manpower for industry 4.0 Readiness," $9^{\text {th }}$ Meeting of the OECD Southeast Asia regional Policy Network on Education and Skills. [book elektronik] 2017

[3] FIMI Dataset Repository, http://www.kemenperin.go.id/artikel/17508/Industri-4.0-Ciptakan-PeluangBaru/ Retrieved 03 Mei, 2017.

[4] Sudira, Putu., "Filosofi dan teori pendidikan Vokasi dan Kejuruan. Yogyakarta, UNY Press., 2012.

[5] Gilbert., Jones, M.G.,E-Learning is e-nomous [Versi ELektronik]. Electric Perspectives, 26 (3), 66-82 (2001).

[6] Khan,B., "Managing e-learning: design, delivery, implementation and evaluation." Hershey,PA: information science Publishing, 2005.

[7] Mahande,R.D, Jasruddin: Utilization Study of mobile at a Vocational hight school, World Transactions on Enginering and Teknology Education 15 (2), 1-7 (2017).

[8] Reis,R.,Escudeiro,P., \& Escudeiro,N. Education resources for mobile wireless devices: a case study [versi Elektronik]. 2012IEEE Internasional Conference on wireless, 264-267 (2012).

[9] Kamp, Simon., "Digital In 2017 Global Overview: A collection, Social Media, And Mobile Data From Around The world. Hootsuite. 2017.

[10] Marius, P., \& Anggoro, S. Profil Pengguna Internet Indonesia 2014. APJII Jkt. (2015)

[11] Susanna I.Herrera, Marta C. Fennema, Maria I. Morales, Rosa A. Palavecino, Jose E. Goldar, Silvia V.Zuain, "Mobile Technology in Engineering Education," Procedding of IEEE International Conference on Interactive Collaborative Learning, IEEE Press, 4799-8706 (2015).

[12] Mehdipour, Y., Zerehkafi, Hamideh., "Mobile Learning for Education: Benefit and Challenges," Internasional Journal of computational Engineering Research 03 (06), 93-101 (2013).

[13] El-Hussein, Muhammad, Osman, M. Cronje, C. Johannes. Defining Mobile learning In the higher Education Landscape. Internasional Forum of education Technology and Society 13 (3), 12-21 (2010).

[14] Rupert Evans. Foundations of Vocational education. Columbus, Ohio, USA: Charless E. Merril Publishing Company. 1971.

[15] Thomson, J.F., “Foundations Of Vocational Education. New Jersey: Prentice Hall. 1973.

[16] Pavlova, M. Technology and Vocational education for sustainable development: Empowering Individuals for the future, ". Australia: Springer. 2009.

[17] Georgiev., TS, Georgieva, E., \& Smrikarov, A. M-learning is a new stage of e-learning. Proceedings of the International Conference on Computer Systems and TechnologyCompSysTech,IV (28). 1-5 (2004).

[18] Hashemi, M., et.al. what is mobile learning? Challeges and capabilities. Procedia-social and Behavioral Sciences, 30, 2477-2481 (2011)

[19] Mcconatha, D., Praul, M., Lynch, J, Michael. "Mobile learning In Higher education: An empirical Assesment Of a new Educational Tool,”. The Turkish online Journal of Educational Technology 7 (3), 1303-6521 (2008). 